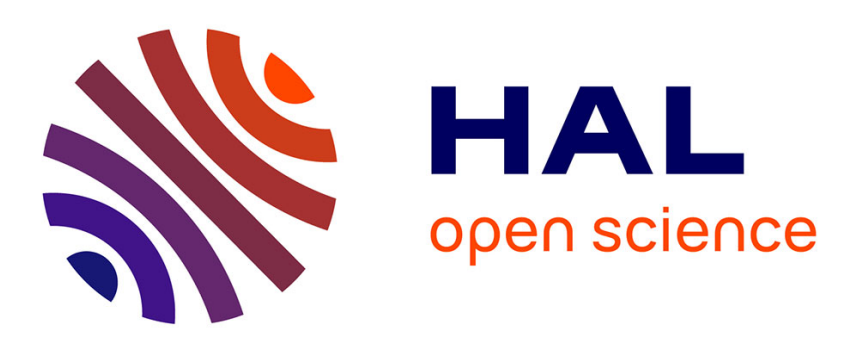

\title{
The electrochemical oxidation: A new way for preparing highly oxidized ferrites
}

\author{
Jean-Claude Grenier, Alain Wattiaux, Michel Pouchard, Léopold Fournès, \\ Jean Etourneau
}

\section{- To cite this version: \\ Jean-Claude Grenier, Alain Wattiaux, Michel Pouchard, Léopold Fournès, Jean Etourneau. The electrochemical oxidation: A new way for preparing highly oxidized ferrites. Journal de Physique IV Proceedings, 1997, 07 (C1), pp.49-52. 10.1051/jp4:1997107 . jpa-00254717}

\section{HAL Id: jpa-00254717 https://hal.science/jpa-00254717}

Submitted on 1 Jan 1997

HAL is a multi-disciplinary open access archive for the deposit and dissemination of scientific research documents, whether they are published or not. The documents may come from teaching and research institutions in France or abroad, or from public or private research centers.
L'archive ouverte pluridisciplinaire HAL, est destinée au dépôt et à la diffusion de documents scientifiques de niveau recherche, publiés ou non, émanant des établissements d'enseignement et de recherche français ou étrangers, des laboratoires publics ou privés. 


\title{
The Electrochemical Oxidation: a New Way for Preparing Highly Oxidized Ferrites
}

\author{
J.-C. Grenier, A. Wattiaux, L. Fournes, M. Pouchard and J. Etourneau \\ Institut de Chimie de la Matière Condensée de Bordeaux, C.N.R.S., Château Brivazac, \\ avenue du Dr. Schweitzer, 33608 Pessac, France
}

\begin{abstract}
The electrochemical oxidation is depicted as a novel and powerful route for preparing highly oxidized ferrites. The reaction is achieved at room temperature, in air, in alkaline solution (1M KOH or NaOH). This process has been used for preparing various new compounds and especially perovskite-type ferrites such as $\mathrm{SrMO}_{3}\left(\mathrm{M}=\mathrm{Fe}\right.$ or/and Co ) or $\mathrm{Sr}_{2} \mathrm{LaFe}_{3} \mathrm{O}_{9-\varepsilon}$. The characterization of the samples shows that they remain well crystallized after the electrochemical treatment and bulky oxidized. The reaction can be described as an intercalation process of oxygen atoms into the host lattice of the starting material. For instance, the chemical analysis as well as Mossbauer spectroscopy data of $\mathrm{SrFeO}_{3}$ or of $\mathrm{Sr}_{2} \mathrm{FeCoO}_{6}$ reveal iron cations to be exclusively tetravalent. On the other hand, $\mathrm{Sr}_{2} \mathrm{LaFe}_{3} \mathrm{O}_{9 \cdot \varepsilon}$ exhibits at decreasing temperature a disproportionation of the mixed valence of iron. Potentiostatic and galvanostatic experiments have shown that the amount of intercalated oxygen can be controlled and that the process is reversible. A mechanism involving the formation of $\mathrm{O}^{-}$species that can diffuse inside the bulk of the material, is proposed.
\end{abstract}

\section{INTRODUCTION}

In the synthetic chemistry of oxides, obtaining highly oxidized materials requires high oxygen pressures and annealing at rather low temperatures, typically 400 to $700{ }^{\circ} \mathrm{C}$. However, in the last two decades, other ways belonging to the field of the so-called 'Chimie Douce' have been investigated, which allowed to obtain metastable forms of highly oxidized materials. The first one that can be quoted is the chemical oxidation at room temperature, which uses strong oxidizing agents in solution such as $\mathrm{MnO}_{4}^{-}, \mathrm{BrO}^{-}$or $\mathrm{ClO}^{-}$species [1, 2]. Solid-gas reactions with $\mathrm{F}_{2}, \mathrm{Cl}_{2}$ or $\mathrm{NO}_{2}$ gases have also been successfully used at moderate temperatures (typically $t<400^{\circ} \mathrm{C}$ ) [3-6]. In the field of the 'Chimie Douce', the electrochemical processes that use the electric potential as a 'driving force' instead of chemical agents appear very interesting preparation methods, especially in the intercalation chemistry [7]. For instance, they are well known for intercalating cations such as $\mathrm{H}^{+}$, $\mathrm{Li}^{+}$or $\mathrm{Na}^{+}$whose ionic sizes are rather small in oxide host lattices, but oxidizing materials supposes to insert (or add) oxygen anions whose size is rather big ( $\mathrm{r}_{22} \approx 1.40 \AA$ ) since the oxide lattice is oxidized and collapses; therefore, such a reaction seemed quite doubtful. However, in 1990, we demonstrated for the first time the promising possibilities provided by the electrochemical oxidation in alkaline solution for preparing highly oxidized oxides by "Chimie Douce" at room temperature ; that was successfully achieved on $\mathrm{La}_{2} \mathrm{CuO}_{4}$ ceramics for which, surprisingly oxygen overstoichiometry and superconductivity were induced [8, 9]. Then similar experiments were repeated by several groups [10-12]; we described here results more especially concerned with the electrochemical oxidation of some strontium ferrites $\mathrm{Sr}_{2} \mathrm{Fe}_{2} \mathrm{O}_{5}, \mathrm{Sr}_{2} \mathrm{FeCoO}_{5}$ and $\mathrm{Sr}_{2} \mathrm{LaFe}_{3} \mathrm{O}_{8}$.

\section{EXPERIMENTAL AND ELECTROCHEMICAL REACTION}

Electrochemical experiments were carried out at room temperature, in a solution of $1 \mathrm{M} \mathrm{NaOH}$ or $\mathrm{KOH}$, under air or nitrogen flow, in a two compartment cell, using a three electrode device. The working electrode is either a rotating disc electrode $(500-5000 \mathrm{rpm})$ or a fixed electrode, the surface area of which can be large, which allows to prepare a big quantity of material. This working electrode is usually a pellet (density $80-85 \%$ ) but it can be also a crystal or a thin film [13, 14]. Dense pellets $(\varnothing 8 \mathrm{~mm}$, thickness $2 \mathrm{~mm}$, weight $0.4 \mathrm{~g}$ ) were obtained from powders of the starting materials prepared by solid-state reaction.

Electrochemical reactions were carried out either at steady potential $(E=450-800 \mathrm{mV}$, potentiostatic mode $)$ or at constant current intensity ( $\mathrm{I}<1 \mathrm{~mA}$ ), galvanostatic mode). Typical (I,E) curves (Fig. 1) exhibit a current plateau before the oxygen evolution reaction occurring at high anodic potentials according to the reaction :

$$
4 \mathrm{OH}^{-} \longrightarrow \mathrm{O}_{2}{ }^{\lambda}+2 \mathrm{H}_{2} \mathrm{O}+4 \mathrm{e}^{-}, \mathrm{E}_{\mathrm{th}}=0.303 \mathrm{~V} /(\mathrm{Hg} / \mathrm{HgO})
$$

This plateau is the signature of the oxidation process of the material which can be written as follows :

$$
\mathrm{A}_{\mathrm{x}} \mathrm{M}_{\mathrm{z}} \mathrm{O}_{\mathrm{y}}+2 \delta \mathrm{OH}^{-} \longleftrightarrow \mathrm{A}_{\mathrm{x}} \mathrm{M}_{\mathrm{z}} \mathrm{O}_{\mathrm{y}+\delta}+\delta \mathrm{H}_{2} \mathrm{O}+2 \delta \mathrm{e}^{-}
$$


According to the Nernst relation ( $\mathrm{E}=\mathrm{E}_{\mathrm{th}}+(\mathrm{RT} / 4 F) \ln \left(a_{\mathrm{O}_{2}} /[\mathrm{OH}]^{4}\right)$, the oxygen activity in reaction (l) can be estimated: for usual applied overpotentials $\left(E_{\text {wppl. }}-E_{t_{2}}=\eta_{O_{2}} \approx 0.2 \mathrm{~V}\right.$ ); it is equivalent, at room temperature, to very high oxygen pressures $\left(\mathrm{p}_{2} \approx 10^{15} \mathrm{~Pa}\right)$, which might explain why such a reaction is achieved.

Accurately weighed amounts of $\mathrm{SrCO}_{3}, \mathrm{La}_{2} \mathrm{O}_{3}$

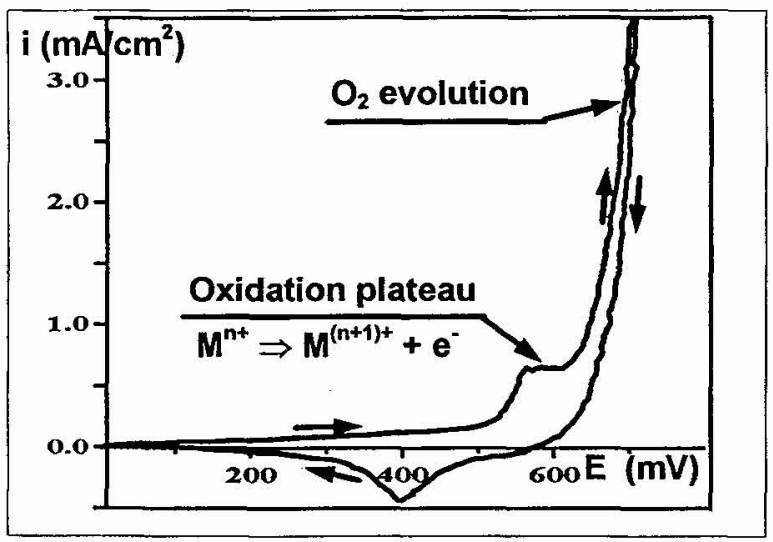

Fig. 1 Typical oxidation plateau observed in a cyclic voltammogram of an oxide and $\mathrm{Co}$ and $\mathrm{Fe}$ nitrates (of high purity) were dissolved in diluted nitric acid $\left(\mathrm{HNO}_{3} / \mathrm{H}_{2} \mathrm{O}=1 / 1\right)$ and dried. So formed powder was slowly fired up to $1473 \mathrm{~K}$ and annealed for $48 \mathrm{~h}$ before quenching in air. Pellets were pressed under an uniaxial pressure of $2 \mathrm{MPa}$ for 2 minutes and finally annealed for $2 \mathrm{~h}$ before quenching in liquid nitrogen. The final thermal treatment was : for $\mathrm{Sr}_{2} \mathrm{Fe}_{2} \mathrm{O}_{5}, 1273 \mathrm{~K}$ under a flow of argon, for $\mathrm{Sr}_{2} \mathrm{FeCoO}_{5}$, $1473 \mathrm{~K}$ in air and for $\mathrm{Sr}_{2} \mathrm{LaFe}_{3} \mathrm{O}_{8}, 1173 \mathrm{~K}$ in purified argon.

The characterization of samples was achieved by X-ray diffraction and chemical analysis using the Mohr's salt method. The as-prepared samples show the orthorhombic symmetry characterizing the brownmillerite-type or G-type structures as well as the expected oxygen stoichiometry. These structures represented in Fig. 2, are built up of 1 or 2 octahedral layers separated by a tetrahedral one in which oxygen vacancy rows can be clearly seen along directions equivalent to the $[110]_{C}$ of the cubic perovskite cell.

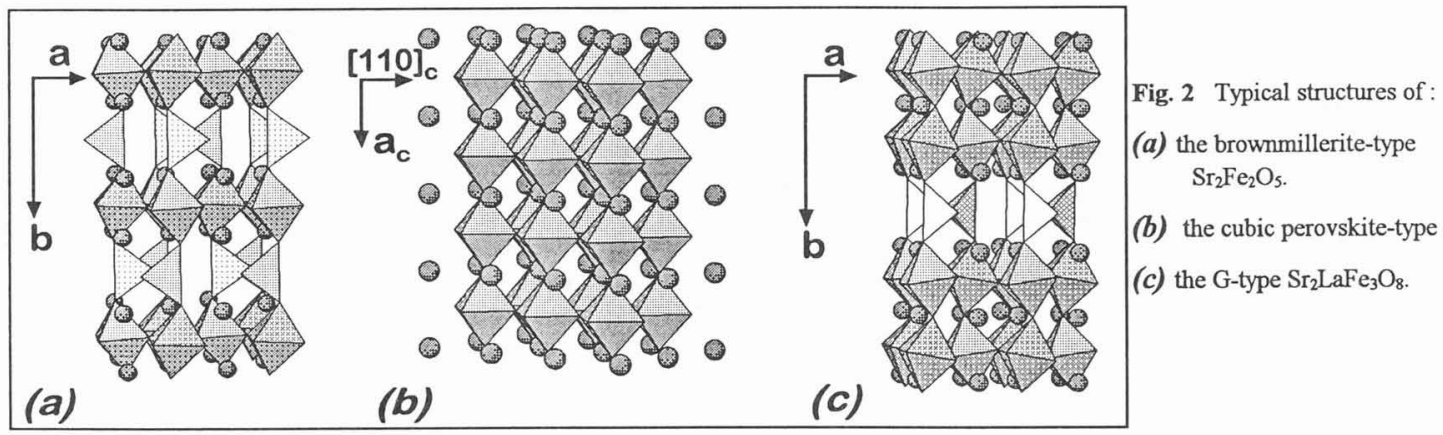

3. RESULTS

Table I summarizes the electrochemical conditions of oxidation and the final composition of the oxidized ferrites. Table I

\begin{tabular}{|c|c|c|c|c|}
\hline $\begin{array}{c}\text { Starting } \\
\text { compound }\end{array}$ & $\begin{array}{c}\text { Electrochemical } \\
\text { conditions }\end{array}$ & $\begin{array}{c}\text { Final } \\
\text { composition }\end{array}$ & $\begin{array}{c}\text { Cell parameter } \\
\left(\mathrm{a}_{c} \text { pm) }\right.\end{array}$ & $\begin{array}{c}\Delta V / V \\
(\%)\end{array}$ \\
\hline $\mathrm{Sr}_{2} \mathrm{Fe}_{2} \mathrm{O}_{5}$ & $400 \mathrm{mV} ; 60 \mathrm{~h}$. & $\mathrm{SrFeO}_{3}$ & $384.5(2)$ & -6.3 \\
\hline $\mathrm{Sr}_{2} \mathrm{FeCoO}_{5}$ & $\mathbf{I}=250 \mu \mathrm{\mu A} ; 9$ days & $\mathrm{Sr}_{2} \mathrm{FeCoO}_{6}$ & $383.7(2)$ & -6.7 \\
\hline $\mathrm{Sr}_{2} \mathrm{LaFe}_{3} \mathrm{O}_{8}$ & $\mathbf{5 0 0 \mathrm { mV } ; 8 \text { days }}$ & $\mathrm{Sr}_{2} \mathrm{LaFe}_{3} \mathrm{O}_{8.90}$ & $387.7(2)$ & -5.2 \\
\hline
\end{tabular}

$\mathrm{Sr}_{2} \mathrm{Fe}_{2} \mathrm{O}_{5}$ was oxidized at constant potential, for 60 hours, which finally involved $\Delta \mathrm{E}_{\mathrm{OCV}}$ (Open Circuit Potential) $\approx$ $400 \mathrm{mV}$ [15]. $\mathrm{Sr}_{2} \mathrm{FeCOO}_{5}$ was oxidized for a duration calculated as the time necessary for the total charge transfer of $2 \mathrm{e}^{-}$ $/ \mathrm{Sr}_{2} \mathrm{CoFeO}_{5}$ (corresponding to the complete oxidation $\delta=1$ ) using the following formula $t=2 \delta \mathrm{m} F / \mathrm{MI}$ (m being the sample mass, $M$ its molecular weight, $I$ the oxidation current, $F$ the Faraday constant); however, assuming a part of the current to be used for the oxygen evolution, an additional polarization time was added [16]. $\mathrm{Sr}_{2} \mathrm{LaFe}_{3} \mathrm{O}_{8}$ was obtained using either the potentiostatic method ( $500 \mathrm{mV}$ for 8 days) or the galvanostatic one $(100 \mu \mathrm{A}$ for 20 days).

After electrochemical oxidation all samples show $\mathrm{X}$-ray diffractograms characterizing a well crystallized material with the cubic perovskite-type pattern. The chemical composition is close to the expected oxygen composition for stoichiometric perovskite attesting that the oxygen intercalation is complete (or almost complete for $\mathrm{Sr}_{2} \mathrm{LaFe} \mathrm{O}_{8}$ ). Comparing the unit cell parameter $a_{C}$ with the mean reduced cell parameter of the starting material, one can point out a significant 
volume shrinkage $(\approx 6 \%)$ due to the oxidation process leading to the occurrence tetravalent $\mathrm{Fe}(\mathrm{IV})$ or $\mathrm{Co}$ (IV) whose ionic radii are somewhat smaller than those or $\mathrm{Fe}(\mathrm{III})$ or $\mathrm{Co}$ (III).

In addition, these compounds exhibit a metallic (or semi-metal) behavior while the starting materials are insulating. From a magnetic viewpoint, they are all antiferromagnetically ordered before oxidation and, when fully oxidized, $\mathrm{SrFeO}_{3}$ shows helimagnetism below $\mathrm{T}_{\mathrm{N}}=140 \mathrm{~K}, \mathrm{Sr}_{2} \mathrm{FeCOO}_{6}$ becomes ferromagnetic below $\mathrm{T}_{\mathrm{C}}=327 \mathrm{~K}$, and exhibit a drastic magnetic transition at $195 \mathrm{~K}$ assigned to the spin ordering and charge disproportionation (see below).

Starting materials as well as oxidized samples were also characterized using Mossbauer spectroscopy. The Mössbauer resonance spectra were obtained with a constant acceleration Halder-type spectrometer with a room temperature ${ }^{57} \mathrm{Co}(\mathrm{Rh}$ matrix) source in a transmission geometry in the range of temperatures $4.2 \leq \mathrm{T} \leq 350 \mathrm{~K}$. The spectra were fitted to the sum of Lorentzians by a least squares refinement ; all isomer shifts given in this study refer to $\alpha-\mathrm{Fe}$ at $293 \mathrm{~K}$.

All starting materials exhibit Mössbauer spectra characterizing magnetically ordered materials and trivalent iron in octahedral $\left(\mathrm{O}_{\mathrm{h}}\right)$ and tetrahedral $\left(\mathrm{T}_{d}\right)$ sites. Typical spectra are given in Fig. 3. The intensity ratio between these lines well agree with the distribution of iron in both sites with regard to the structure : for $\mathrm{Sr}_{2} \mathrm{Fe}_{2} \mathrm{O}_{5}, \mathrm{O}_{\mathrm{b}} / \mathrm{T}_{\mathrm{d}}=47 / 53$, for $\mathrm{Sr}_{2} \mathrm{FeCoO}_{5}$, $\mathrm{O}_{\mathrm{b}} \mathrm{T}_{\mathrm{d}}=46 / 54$ (Fig. 3a), which implies a random occupancy of iron and cobalt in both sites, and for $\mathrm{Sr}_{2} \mathrm{LaFe}_{3} \mathrm{O}_{8}$ (Fig. 3b), $\mathrm{O}_{\mathrm{h}} / \mathrm{T}_{\mathrm{d}}=68 / 32$.

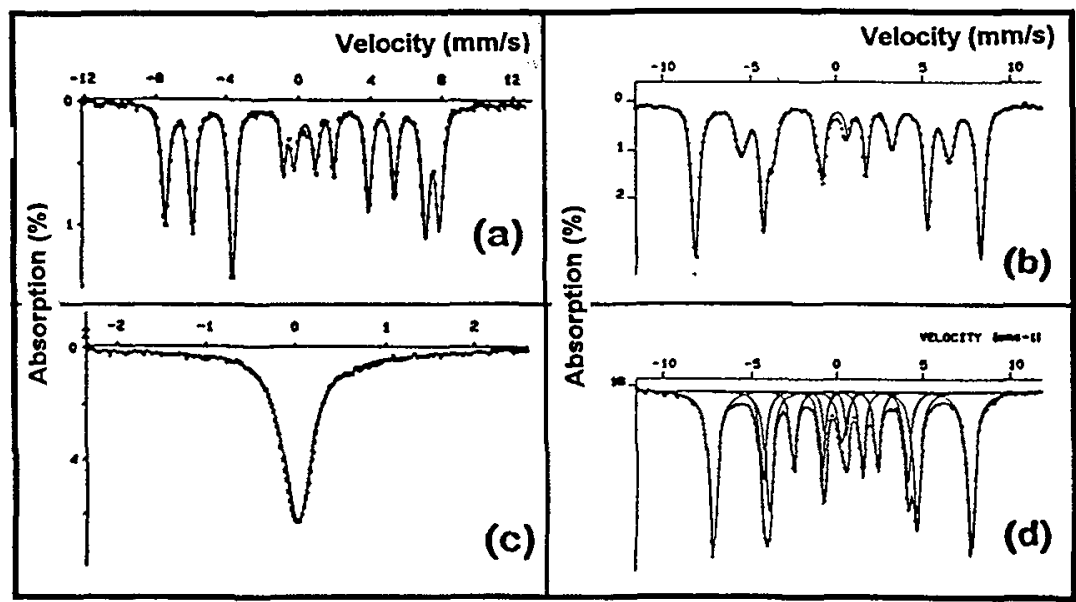

Fig. 3 Mossbauer resonance spectra of : (a) $\mathrm{Sr}_{2} \mathrm{FeCoO}_{5}$ at $295 \mathrm{~K}$; (b) $\mathrm{Sr}_{2} \mathrm{LaFe}_{3} \mathrm{O}_{8}$ at $295 \mathrm{~K}$ (c) $\mathrm{Sr}_{2} \mathrm{FeCoO}_{6}$ at $340 \mathrm{~K}$ (d) $\mathrm{Sr}_{2} \mathrm{LaFe}_{3} \mathrm{O}_{8.90}$ at $4.2 \mathrm{~K}$

After electrochemical oxidation, the spectra show a complete change and no trace of the starting materials. All patterns exhibit paramagnetic lines whose Mössbauer parameters characterize the oxidation of trivalent iron :

- for $\mathrm{SrFeO}_{3}$, at $293 \mathrm{~K}$, it is a single symmetrical line $(\delta=$ $0.082 \mathrm{~mm} / \mathrm{s}$ ) demonstrating the presence of only $\mathrm{Fe}$ (IV).

- for $\mathrm{Sr}_{2} \mathrm{FeCoO}_{6}$ (Fig. 3c), the thermal dependence of the spectra shows that the magnetic ordering Curie temperature $T_{\varepsilon}$ is close to $327 \mathrm{~K}$ in agreement with magnetic susceptibility data. Above $T_{c}$, at $340 \mathrm{~K}$, the spectrum was fitted by a broad single line with $\delta=0.07 \mathrm{~mm} / \mathrm{s}$ charac-

terizing again the presence of $\mathrm{Fe}$ (IV).

- for $\mathrm{Sr}_{2} \mathrm{LaFe}_{3} \mathrm{O}_{8.90}$, at room temperature, the spectrum exhibit a single symmetrical line, somewhat broadened, which was fitted by a quadrupolar doublet $(\Delta=0.16 \mathrm{~mm} / \mathrm{s})$; the value of the isomer shift $(\delta=0.14 \mathrm{~mm} / \mathrm{s})$ is characteristic of a mixed valence of iron and, as expected, intermediate of $\mathrm{Fe}(\mathrm{III})$ and $\mathrm{Fe}(\mathrm{IV})$, which implies a fast electron transfer. At decreasing temperature magnetic ordering is observed below $195 \mathrm{~K}$ and, at $4.2 \mathrm{~K}$, two sextets can be observed (Fig. 3d). The Mössbauer parameters $\left(\delta_{1}=0.36 \mathrm{~mm} / \mathrm{s}, H_{1}=46.6 \mathrm{~T}\right.$ and $\left.\delta_{2}=-0.03 \mathrm{~mm} / \mathrm{s}, H_{2}=26.4 \mathrm{~T}\right)$ involve a charge disproportionation of the average mixed valence of iron into $\mathrm{Fe}^{(3+\lambda)+}$ and $\mathrm{Fe}^{(5-2)+}$. The intensity ratio $\mathrm{I}_{1} / \mathrm{I}_{2}=70 / 30$ well agrees with the chemical analysis.

\section{CONCLUSION : CONSIDERATIONS ABOUT THE ELECTROCHEMICAL PROCESS}

These experiments being performed in concentrated $[\mathrm{OH}]$ solution, one should address the question about the nature of the intercalated species, the formation of oxyhydroxides being the most obvious assumption. Early works using T.G.A., ${ }^{\text {H}}$ N.M.R. as well as I.R. spectroscopy clearly demonstrated the absence of $(\mathrm{OH})$ species in the final oxidized materials [17]. The above reported results clearly show that it is indeed oxygen atoms that have been intercalated, which nicely corroborates the reaction (2). Such conclusions were also confirmed by quantitative galvanostatic experiments at very low current intensity, the results being in excellent agreement with iodometric titration of the samples [10]. As $\mathrm{O}^{2-}$ anions, with respect to their ionic size, are not likely to be the diffusing species, therefore the addressed question is : which are the diffusing species ?

The oxidation process occurring at potentials close to the oxygen evolution reaction, we assumed that this process should involve electroactive species concerned with the mechanism of the oxygen evolution.

Various electrochemical studies have been carried out (cyclic voltammetry $\left(I_{o x} v s . v^{-1 / 2}\right.$ (sweep rate) or Tafel behavior $(\log (E)=f(i))$, experiments at steady potential $I_{o x}$ vs. $t^{-1 / 2}$ (time) $\left.[18,19]\right)$, which led to conclude to the formation, at the surface of the electrode, of $\mathrm{O}^{-}$species that are immediately consumed and to determine the value of the diffusion 
coefficient $D_{\text {ox }}$ of the electroactive species to be about $10^{-9}-10^{-11} \mathrm{~cm}^{2} / \mathrm{s}$. This value appears somewhat greater than the value usually found for the $\mathrm{O}^{2-}$ diffusion in oxides at room temperature $\left(<10^{-15} \mathrm{~cm}^{2} / \mathrm{s}\right)$. Therefore, we proposed the oxygen diffusion to be possible thanks to the formation of $\mathrm{O}^{-}$species considering that most oxides concerned by electrochemical oxidation belong to the class of materials [20] for which the following equilibrium, $\mathrm{M}^{(\mathrm{n}+1)}+\mathrm{O}^{2-} \Leftrightarrow \Rightarrow \mathrm{M}^{\mathrm{n}+}+\mathrm{O}^{-}$, is characterized by a very small energy $\Delta(\approx 0 \mathrm{eV}$, the charge transfer energy), which involves the existence of a mixed valence of oxygen $\left(\mathrm{O}^{2} / \mathrm{O}\right)$ or, in other words, an easy electron transfer from the oxygen to the metal cation. Then, one may expect that the formation of $\mathrm{O}^{-}$species is rather easy which would explain why oxygen atoms can easily move into the oxide network, even at nearly room temperature. Such a mobility was early reported by Jorgensen et al. [21] from neutron diffraction experiments and also from NMR data, conductivity measurements ...[22]. However, such a migration requires easy diffusion paths within the parent structure ; in brownmillerite compounds or G-type compounds, this path clearly appears along $[001]_{0} \equiv[110]_{\text {per. }}$ vacancy files (Fig. 2).

Recently discovered the electrochemical oxidation has rapidly appeared as a powerful technique of 'Chimie Douce' for bulky oxidizing oxides, capable to replace the use of high oxygen pressures in some specific cases. The preparation and the characterization of some fully oxidized ferrites has clearly demonstrated the intercalation of oxygen to be successful. Various new 'overoxidized' oxides (such as the superconducting cuprate $\mathrm{La}_{2} \mathrm{CuO}_{4.09}[8,23]$ ) have been thus prepared in a metastable state. The galvanostatic mode appears however the most efficient way for controlling the kinetics of this process.

\section{Acknowledgements:}

The authors are grateful to P. Bezdicka, A. Demourgues and Z. Fang for their contribution to this work.

\section{Références}

[1] E. Takayama-Muromachi, T. Sasaki and Y. Matsui, Physica C, 207, (1993) 97-101.

[2] M. Trari, J. Töpfer, J-P. Doumerc, M. Pouchard, A. Ammar and P. Hagenmuller. J. Sol. State Chem., 111, (1994) 104110.

[3] B. Chevalier, A. Tressaud, B. Lepine, K. Amine, J.M. Dance, L. Lozano, E. Hickey and J. Etourneau, Physica C, 167, (1990) 97-101.

[4] E. E. Fadeeva, E.I. Ardashnikova, B.A. Popovkin and M. P. Borzenkova, Russian J. Inorg. Chem., 38, (1993) 363-372.

[5] A. Tressaud, C. Robin, B. Chevalier, L. Lozano and J. Etourneau, Physica C, 177, (1991) 330-336.

[6] S. Petit, J-P. Doumerc, J.C. Grenier, T. Seguelong. and M. Pouchard, C.R. Acad. Sci; 321(II), (1995) 37-41.

[7] M.S. Witthingham, "Intercalation Chemistry" (M.S. Witthingham and A.J.Jacobson, Eds.), Mat. Sci. Series, Academic Press, New York, (1982) p. 1.

[8] A. Wattiaux, J-C. Park, J-C. Grenier and M. Pouchard, C. R. Acad. Sci. Paris, 310 (II), (1990) 1047-1052.

[9] J-C. Grenier, A. Wattiaux, N. Lagueyte, J.C. Park, E. Marquestaut, J. Etourneau and M. Pouchard, Physica C, 173, (1991) 139-144.

[10] F.C. Chou, J.H. Cho and D.C. Johnston, Physica C, 197, (1992) 303-314.

[11] J.D. Di Carlo, I. Yazdi, S. Bhavaraju, and A.J. Jacobson, Chem. Mater., 5, (1993) 1692-1696.

[12] N. Casan-Pastor, P. Gomez-Romero, A. Fuertes, J. M. Navarro, M. J. Sanchis and S. Ondono, Physica C, 216, (1993) 478-490.

[13] F.C. Chou, D.C. Johnston, S.W. Cheong and P.C. Canfield, Physica C, 216, (1993) 66-72.

[14] F. Arrouy, J-P. Locquet, E.J. Williams, E. Mächler, R. Berger, C. Gerber, C. Monroux, J-C. Grenier and A. Wattiaux. Phys. Rev. B, (in press) (1996).

[15] A. Wattiaux, L. Fournes, A. Demourgues, N. Bernaben, J-C. Grenier and M. Pouchard., Sol. State Commun.., 77, (1991) 489-493.

[16] P. Bezdicka, L. Fournes, A. Wattiaux, J.C. Grenier and M. Pouchard, Sol. State Commun., 91(7), (1994) 501-507.

[17] J.C. Park, P.V. Huong, M. Rey-Lafon, J-C. Grenier, A. Wattiaux and M. Pouchard., Physica C, 177, (1991) 487-493.

[18] P. Bezdicka, A. Wattiaux, J-C. Grenier and M. Pouchard, Electrochem. Acta, (in press) and P. Bezdicka, Ph.D., Univ. of Bordeaux, \# 988 (1993).

[19] J.C. Grenier, F. Arrouy, J-P. Locquet, C. Monroux, M. Pouchard, A. Villesuzanne and Wattiaux, "Phase separation in cuprates" (Ed. by K.A. Müller et G. Benedeck, World Scientific, Singapore), (1994) 237-256.

[20] J.B. Torrance, P. Lacorre, C. Asavaroengchai and R.M. Metzger, J. Sol. State Chem., 90, (1991) 168-173.

[21] J.D. Jorgensen, B. Dabrowski, S. Pei, D.R. Richards and D.G. Hinks, Phys. Rev B, 40, (1989) 2187-2196.

[22] S. Rubini, F. Borsa, P. Canfield, F.C. Chou, Q. Hu, A. Lascialfari, D.C. Johnston, A. Rigamonti and D.R.

Torgeson, Physica C, 235-240, (1994) 1717-1723.

[23] J-C. Grenier, N. Lagueyte, A. Wattiaux J.P. Doumerc, P. Dordor, J. Etourneau, J.B. Goodenough, J.S. Zhou and M. Pouchard, Physica C, 202, (1992) 209-218. 